\title{
Extract of the paper "Technique to evaluate the thermoregulatory capacity before thermal stress. Application case of thermographic images to blood flow monitoring"
}

\author{
Pablo Rodríguez-Gonzálvez ${ }^{1, *}$, Manuel Rodríguez-Martín ${ }^{2,3}$, Iván Rodríguez-Miró ${ }^{4}$, Sara \\ Fernández-Iglesias ${ }^{4}$, Ángeles de Alda Bernal ${ }^{4}$, Ildefonso Alvear-Órdenes ${ }^{5}$ \\ ${ }^{1}$ Department of Mining Technology, Topography and Structures, Universidad de León, 24401 \\ Ponferrada, Spain. Email: p.rodriguez@unileon.es \\ ${ }^{2}$ Technological Department. Catholic University of Avila. C/Canteros SN. 05005, Ávila, Spain. \\ Email: manuel.rodriguez@ucavila.es \\ ${ }^{3}$ Department of Mechanical Engineering, University of Salamanca, 37700 Béjar, Spain. Email: \\ ingmanuel@usal.es \\ ${ }^{4}$ Department of Nursing and Physiotheraphy, Universidad de León, 24401 Ponferrada, Spain. \\ Email: irodrm06@estudiantes.unileon.es; sferni02@estudiantes.unileon.es; \\ mdealb00@estudiantes.unileon.es \\ ${ }^{5}$ Institute of Biomedicine (IBIOMED) / Department of Biomedical Sciences, Universidad de \\ León, 24401 Ponferrada, Spain. Email: ialvor@unileon.es
}

\begin{abstract}
In order to improve the acquisition of skills in nursing and physiotherapy, a new learning methodology is presented. To this end, a laboratory practice based on the combination of thermographic technologies and clinical practice is shown. The thermographic images are used for the evaluation of the thermoregulatory system of the hands, with particular emphasis on Raynaud's syndrome or phenomenon. In Raynaud's syndrome, alterations in surface temperature occur in peripheral regions such as the hands. In this methodological practice, thermographic information is evaluated to observe the physiological response to thermal stress, information that can be handled by students via e-learning. It is a protocol model of thermal stress by immersing hands in cold water. The present work is related to the application of infrared technology that can be used not only for the acquisition of practical skills, but also for the evaluation of competencies in the area of health sciences. In this practical project the student is able to apply complex competences in the field that will be developed throughout their career in both clinical and / or research.
\end{abstract}

\section{Citation}

P. Rodríguez-Gonzálvez, M. Rodríguez-Martín, I. Rodríguez-Miró, S. FernándezIglesias, M.Á. de Alda Bernal, and I. Alvear-Ordenes. 2019. Technique to evaluate the thermoregulatory capacity before thermal stress. Application case of thermographic images to blood flow monitoring. In Proceedings of the Seventh International Conference on Technological Ecosystems for Enhancing Multiculturality (TEEM'19). Association for Computing Machinery, New York, NY, USA, 416-422. DOI: https://doi.org/10.1145/3362789.3362872 


\section{Keywords}

Educational innovation; ICT; E-Learning; Engineering; Thermography; Circulatory physiology

\section{Link to the publisher}

https://dl.acm.org/doi/10.1145/3362789.3362872

\section{References}

[1] David Álvarez Prats and Óscar Carbajal Fernández. 2017. Termografía en fisioterapia. In: I Congreso Nacional de Fisioterapia en el Deporte. Elsevier España. Logroño, Spain, 249262.

[2] Fernando Ignacio de Prada Pérez de Azpeitia. 2016. La termografía infrarroja: un sorprendente recurso para la enseñanza de la física y la química. Revista Eureka sobre Enseñanza y Divulgación de las Ciencias, 13, 3, 617-627.

[3] Paul G. Hewitt. 2004. Física conceptual ( $9^{\text {th }}$ Edition). México: Pearson Educación.

[4] Edward Francis J. Ring and Kurt Ammer. 2012. Infrared thermal imaging in medicine. Physiological measurement, 33, 3, R33-R46. DOI: https://dx.doi.org/10.1088/0967$\underline{3334 / 33 / 3 / R 33}$

[5] Denise S Haddad, ML Brioschi and Emiko Saito Arita. 2012. Thermographic and clinical correlation of miofascial trigger points in the masticatory muscles. Dentomaxillofacial Radiology, 41, 8, 621-629. DOI: https://doi.org/10.1259/dmfr/98504520

[6] Geetika Dua and Ravibabu Mulaveesala. 2018. Applicability of active infrared thermography for screening of human breast: a numerical study. Journal of Biomedical Optics, 23, 3, 1-9. DOI: https://doi.org/10.1117/1.JBO.23.3.037001

[7] Ildefonso Alvear-Ordenes. 2017. Consolidación de una práctica integradora en fisiología humana. Infancia, Educación y Aprendizaje (IEYA), 3, 2, 429-433. DOI: http://dx.doi.org/10.22370/ieya.2017.3.2.760

[8] Pablo Rodríguez-Gonzálvez, Manuel Rodríguez-Martín, Beatriz Alonso-Cortés Fradejas and Ildefonso Alvear-Ordenes. 2018. 3D Visualization Techniques in Health Science Learning. Application case of Thermographic Images to Blood Flow Monitoring. In Proceedings of Sixth International Conference on Technological Ecosystems for Enhancing Multiculturality (TEEM'18). ACM, New York, NY, USA, 373-380. DOI: https://doi.org/10.1145/3284179.3284243

[9] Eduardo Hidalgo Salvador, Fernando Álvarez González and Adolfo Salvador Luna. 2014. Application of infrared thermography in legal medicine. Is it a valid test for an objective assessment of painful syndromes? Temporomandibular disorder. Cuaderno de Medicina Forense, 20, 2-3, 77-84. DOI: http://dx.doi.org/10.4321/S1135-76062014000200002

[10] Norman D. Mohl, Richard K. Ohrbach, Heidi C. Crow and Alan J. Gross. 1990. Devices for the diagnosis and treatment of temporomandibular disorders. Part III: Thermography, 
ultrasound, electrical stimulation, and electromyographic biofeedback. The Journal of Prosthetic Dentistry, 63, 4, 472-477.

[11] Almir Vieira Dibai-Filho, Amanda Carine Packer, Ana Claudia de Souza Costa and Delaine Rodriguez-Bigaton. 2014. The chronicity of myogenous temporomandibular disorder changes the skin temperature over the anterior temporalis muscle. Journal of bodywork and movement therapies, 18, 3, 430-434. DOI: https://doi.org/10.1016/j.jbmt.2013.11.001

[12] Carmen Pichot. 2001. Aplicación de la termografía en el dolor lumbar crónico. Revista de la Sociedad Española del Dolor, 8, 2, 43-47.

[13] Carolin Hildebrandt, Christian Raschner and Kurt Ammer. 2010. An overview of recent application of medical infrared thermography in sports medicine in Austria. Sensors, 10, 5, 47004715. DOI: https://dx.doi.org/10.3390/s100504700

[14] Joao Carlos Bouzas Marins, Alex de Andrade Fernandes, Danilo Gomes Moreira, Fernando Souza Silva, Carlos Magno Amaral Costa, Eduardo Mendoça Pimenta and Manuel Sillero Quintana. 2014. Thermographic profile of soccer players' lower limbs. Revista Andaluza de Medicina del Deporte, 7, 1, 1-6.

[15] Aral Hakgüder, Murat Birtane, Suleyman Gürcan, Siranus Kokino and Fatma Nesrin Turan. 2003. Efficacy of low level laser therapy in myofascial pain syndrome: an algometric and thermographic evaluation. Lasers in Surgery and Medicine, 33, 5, 339-343. DOI: https://doi.org/10.1002/1sm.10241

[16] Jakub Taradaj, Andrzej Franek, Edward Blaszczak, Anna Polak, Daria Chmielewska, Piotr Krol and Patrycja Dolibog. 2012. Physical therapy in the treatment of venous leg ulcers: biophysical mechanisms. Wounds, 24, 5, 138-145.

[17] Ariane L. Herrick and Andrea Murray. 2018. The role of capillaroscopy and thermography in the assessment and management of Raynaud's phenomenon. Autoimmunity Reviews, 17, 5, 465-472. DOI: https://doi.org/10.1016/j.autrev.2017.11.036

[18] National Resident Matching Program. Results and Data. 2013. Main Residency Match ${ }^{\circledR}$. National Resident Matching Program: Washington, DC.

[19] Catherine M O'connor. 2001. Raynaud's phenomenon. Journal of Vascular Nursing, 19, 3, 87-92. DOI: https://doi.org/10.1067/mvn.2001.117786

[20] Beth Goundry, Laura Bell, Matthew Langtree and Arumugam Moorthy. 2012. Diagnosis and management of Raynaud's phenomenon. British Medical Journal, 344, e289. DOI: https://doi.org/10.1136/bmj.e289

[21] Diego González-Aguilera, Susana Lagueela, Pablo Rodríguez-Gonzálvez and David Hernández-López. 2013. Image-based thermographic modeling for assessing energy efficiency of buildings façades. Energy and Buildings, 65, 29-36. DOI: https://doi.org/10.1016/j.enbuild.2013.05.040

[22] Manuel Gesto-Diaz, Federico Tombari, Diego Gonzalez-Aguilera, Luis LopezFernandez, and Pablo Rodriguez-Gonzalvez 2017. Feature matching evaluation for multimodal correspondence. ISPRS Journal of Photogrammetry and Remote Sensing, 129, 179-188. DOI: https://doi.org/10.1016/j.isprsjprs.2017.05.007 
[23] Waldemar Minkina and Sebastian Dudzik. 2009. Infrared thermography: errors and uncertainties. John Wiley \& Sons

[24] Ellen Keenan, Georgina Gethin, Louisa Flynn, David Watterson and Gerard M. O'Connor. 2017. Enhanced thermal imaging of wound tissue for better clinical decision making. Physiological measurement, 38, 6 (May 2017), 1104-1115. DOI: https://doi.org/10.1088/1361$\underline{6579 / \mathrm{aa6ea} 0}$

[25] Manuel Rodríguez-Martín and Pablo Rodríguez-Gonzálvez. 2018. Learning based on 3D photogrammetry models to evaluate the competences in visual testing of welds. In Proceedings of the 2018 IEEE Global Engineering Education Conference. IEEE. Santa Cruz de Tenerife, Spain, 1582-1587. DOI: https://doi.org/10.1109/EDUCON.2018.8363422

[26] Vergara, Manuel Rodríguez-Martín, Manuel Pablo Rubio Cavero, Jesús Ferrer Marín, Francisco Javier Nuñez García and Luisa Moralejo Cobo. 2018. Formación de personal técnico en ensayos no destructivos por ultrasonidos mediante realidad virtual. DYNA, 93 2, 150-154. DOI: http://dx.doi.org/10.6036/8444

[27] Manuel Rodríguez-Martín and Pablo Rodríguez-Gonzálvez. 2019. Materiales formativos 3D desde ingeniería inversa para el aprendizaje de la inspección de soldaduras. DYNA Ingeniería e industria, 94, 3, 238-239. DOI: http://dx.doi.org/10.6036/8798

[28] Hien Nguyen, Ebtissam Wahman, Niki Pissinou, Sitharama S. Iyengar and Kia Makki. 2015. Mobile learning object authoring tool and management system for mobile ad hoc wireless networks. International Journal of Communication Systems, 28, 17, 2180-2196. DOI: https://doi.org/10.1002/dac.2996 